\title{
Kedudukan Akta Fidusia Yang Dibuat Oleh Notaris Yang Diluar Daerah Jabatannya
}

\author{
Dafitson Husthinob ${ }^{*}$, Zulfikar Hanafi Bahri**, Anis Mashdurohatun ${ }^{* * *}$
}
* Mahasiswa Program Magister (S2) Kenotariatan Fakultas Hukum UNISSULA, Semarang email : e-mail: dafitsonhusthinob@gmail.com
** Mahasiswa Program Magister (S2) Ilmu Hukum, Fakultas Hukum UNISSULA, Semarang, e-mail: zulfikarhanafi@ymail.com *** Dosen Fakultas Hukum UNISSULA

\begin{abstract}
ABSTRAK
Pasal 17 Undang-Undang Nomor 2 Tahun 2014 perubahan atas Undang-Undang Nomor 30 Tahun 2004 Tentang Jabatan Notaris yang mengatur bahwa Notaris hanya berwenang untuk membuat akta otentik diwilayah hukum atau wilayah jabatannya, maka akta yang dibuat tidak mempunyai kekuatan sebagai akta notariil.

Problematik penelitian ini adalah : bagaimana pengaturan kedudukan Akta Fidusia dan peran Notaris dalam pembuatan Akta Fidusia?; apakah dibenarkan seorang Notaris membuat Akta Fidusia diluar wilayah jabatannya? dan bagaimana Kedudukan Akta Fidusia yang dibuat Notaris diluar wilayah jabatannya?. Metode yang digunakan dalam penelitian ini adalah dengan pendekatan yuridis-normatif yang bersumber dari pengumpulan data yang diperoleh dari data primer dan data sekunder, kemudian dianalisis dengan metode analisis kualitatif. Teknik pengumpulan data yang digunakan adalah studi kepustakaan (undang-undang, pendapat para ahli dan literaturliteratur buku mengenai penelitian ini). Teknik analisis data menggunakan analisis data kualitatif.

Hasil temuan peneliti menunjukkan bahwa Pasal 5 Ayat (1) Undang- Undang Nomor 42 tahun 1999 tentang Jaminan Fidusia menyebutkan bahwa yang berwenang membuat Akta Fidusia adalah seorang notaris, sedangkan Pasal 17 Undang-Undang Nomor 2 Tahun 2014 perubahan atas Undang-Undang Nomor 30 Tahun 2004 Tentang Jabatan Notaris yang mengatur bahwa Notaris hanya berwenang untuk membuat akta otentik diwilayah hukum atau wilayah jabatannya. Notaris yang melakukan pelanggaran dalam peraturan Undang-undang tentang Jabatan Notaris ataupun melanggar Kode etik notaris akan medapatkan sanksi berupa teguran lisan dan teguran tulis yang selanjutnya akan dijatuhi sanksi administratif, sanksi bisa berupa pemberhentian sementara, pemberhentian dengan hormat bahkan jika kesalahan memang benar-benar sudah fatal dan terbukti melanggar aturan dapat diberikan sanksi berupa pemberhentian secara tidak hormat. Kedudukan hukum terhadap akta yang dibuat oleh notaris yang telah melakukan pelanggaran terhadap undang-undang notaris yaitu akta notaris tersebut dalam pembuatanya dilakukan diluar wilayah jabatan maka akta notaris tersebut tidak otentik dan akta tersebut tidak memiliki kekuatan seperti akta dibawah tangan apabila ditanda tangani oleh para pihak yang bersangkutan.

Saran kepada pemerintah bahwa notaris yang bekerja di luar wilayah kerja wajib sanksi hukumnya ditegakkan dan optimalisasi serta profesionalisme dalam melaksanakan kinerja notaris dalam memberikan pelayanan kepada masyarakat yang membutuhkan lebih berorientasi kerja berbasis kepentingan ekonomi, prestige dan lain-lain yang berada pada lingkaran wilayah kepentingan pribadi hendaknya dapat dikalahkan demi kepentingan umum tanpa melanggar aturan yang berlaku.
\end{abstract}

Kata kunci : Akta Fidusia, Notaris dan Kedudukan Hukum Notaris

\section{ABSTRACT}

Article 17 of Law Number 2 Year 2014 amendment to Law Number 30 Year 2004 Concerning Notary Public Offering stipulating that Notary is only authorized to make an authentic deed in its jurisdiction or territory, the deed is not authorized as a notarial deed

The problematic of this research are: how to regulate the position of Fiduciary Deed and Notary's role in making Fiduciary Deed ?; is it justified by a Notary to make a Fiduciary Deed outside the territory of his / her position? and how is the position of the Fiduciary Deed made by a Notary outside his / her position ? The method used in this research is with the juridical-normative approach derived from data collection obtained from the primary data and secondary data, then analyzed by qualitative analysis method. Data collection techniques used are literature studies (laws, expert opinions and book literature on this thesis). Data analysis techniques used qualitative data analysis.

The findings of the researcher indicate that Article 5 Paragraph (1) of Law Number 42 Year 1999 regarding Fiduciary Guarantee states that the authority to make Fiduciary Deed is a notary while Article 17 of Law Number 2 Year 2014 amendment to Law Number 30 Year 2004 Concerning Position of Notary which stipulates that Notary 
is only authorized to make an authentic deed in its jurisdiction or jurisdiction. A Notary who commits a violation in the Law on Notary Publicity or violates the Notary Code of Ethics shall obtain sanctions in the form of oral and written reprimands which shall be subjected to administrative sanctions, sanctions may be temporary dismissal, dismissal with respect even if the error is indeed fatal and proven to violate the rules can be given sanctions in the form of dismissal in disrespect. The legal status of a deed made by a notary who has committed a violation of a notarial act is that the notary deed is made outside the territory of the notary so that the notarial deed is not authentic and the deed does not have the power as a deed under the hand if it is signed by the parties concerned.

Suggestion to the government that a notary working outside the working area shall be sanctioned by law and optimization and professionalism in carrying out notary performance in providing services to people who need more work-oriented based on economic interests, prestige and others who are in the circle of private interest area should may be defeated in the public interest without violating any applicable rules.

Keywords : Position, Fiduciary Deed and Notary

\section{PENDAHULUAN}

Dalam rangka memelihara dan meneruskan pembangunan yang berkesinambungan, para pelaku pembangunan baik pemerintah maupun masyarakat, baik perseorangan maupun badan hukum memerlukan dana besar. Seiring dengan meningkatnya pembangunan, meningkat pula kebutuhan terhadap pendanaan, yang sebagian besar dana yang diperlukan untuk memenuhi kebutuhan tersebut diperoleh melalui pinjammeminjam. ${ }^{1}$

Selama ini, kegiatan pinjam-meminjam dengan menggunakan hak tanggungan atau hak jaminan telah diatur dalam Undang-Undang Nomor 4 Tahun 1996 tentang Hak Tanggungan Atas Tanah Beserta Benda-Benda yang Berkaitan Dengan Tanah (Undang-Undang Hak Tanggungan/UUHT) yang merupakan pelaksanaan dari Pasal 51 UndangUndang Nomor 5 Tahun 1960 tentang Peraturan Dasar Pokok-Pokok Agraria (UUPA), dan sekaligus sebagai pengganti dari lembaga Hipotek atas tanah dan Credietverband. ${ }^{2}$

Undang-Undang yang berkaitan dengan Jaminan Fidusia adalah Pasal 15 Undang-Undang Nomor 4 Tahun 1992 tentang perumahan dan pemukiman, yang menentukan bahwa rumah-rumah yang dibangun di atas tanah yang dimiliki oleh pihak lain dapat dibebani dengan Jaminan Fidusia. Selain itu Undang-Undang Nomor 16 Tahun 1985 tentang Rumah Susun mengatur mengenai Hak Milik atas satuan rumah susun yang dapat dijadikan jaminan utang dengan dibebani fidusia jika tanahnya tanah hak pakai atas tanah negara. ${ }^{3}$

\footnotetext{
${ }^{1}$ Purwahid Patrik, Kashadi, Hukum Jaminan, Badan Penerbit Universitas Diponegoro, Semarang, 2009, hlm. 171

${ }^{2}$ Mariam D. Badrulzaman, Bab - Bab Tentang Credietverband, Gadai dan Fidusia, Alumni, Bandung, 1978

${ }^{3}$ Ignatius Ridwan Widyadarma, Undang-Undang Hak Tanggungan atas Tanah beserta Benda-Benda yang
}

\section{Metode Penelitian}

Jenis penelitian hukum yuridis normatif, yaitu pendekatan penelitian yang bertujuan untuk menggambarkan fakta atau gejala yang menjadi bahan atau objek dari penelitian tersebut. Terutama dilakukan untuk meneliti hukum yang perumusannya tanpa dikaitkan dengan pendekatan masyarakat, yang kemudian didukung dengan data-data sekunder sebagai refrensi dalam penelitian yang diperoleh dari buku-buku yang kaitannya dengan penelitian.

Metode Pendekatan yang digunakan yaitu: 1) Pendekatan Perundang-undangan (statute approach), Mengkaji bahan-bahan kepustakaan dan peraturan perundang-undangan, baik KUHPerdata, Undang-Undang Nomor 2 Tahun 2014 Tentang Jabatan Notaris, Undang-Undang Nomor 42 Tahun 1999 Tentang Jaminan Fidusia, Peraturan Pemerintah Nomor 21 Tahun 2015 Tentang Pendaftaran Fidusia dan lainnya; 2) Pendekatan Konseptual ( conseptual aproach ), Beranjak dari pandangan-pandangan dan doktrin-doktrin yang berkembang di dalam penulisan Metode Penelitian Hukum.

Jenis dan Sumber Data berupa : 1) Bahan Hukum Primer meluputi : Peraturan perundangundangan; KUHPerdata, Undang-Undang Nomor 2 Tahun 2014 Tentang Jabatan Notaris, UndangUndang Nomor 42 Tahun 1999 Tentang Jaminan Fidusia, Peraturan Pemerintah Nomor 21 Tahun 2015 Tentang Pendaftaran Fidusia, Peraturan Menteri Hukum dan Hak Asasi Manusia Republik Indonesia Nomor 10 Tahun 2013 Tentang Tata Cara Pendaftaran Jaminan Fidusia Online, Peraturan Kapolri Nomor 8 Tahun 2011 Tentang Pengamanan Eksekusi Jaminan Fidusia; 2) Bahan Hukum Sekunder, Buku-buku teks (teksbooks) yang ditulis

Berkaitan dengan Tanah,Badan Penerbit Universitas Diponegoro, Semarang, 1996 
para ahli hukum yang berpengaruh, jurnal jurnal hukum serta hasil-hasil symposium atau seminar yang terkait dengan topik penelitian, Penelitian dan Disertasi; 3) Bahan Hukum Tersier, Bahan yang memberikan petunjuk maupun penjelasan terhadap bahan hukum primer dan sekunder, seperti Kamus Besar Bahasa Indonesia dan Kamus Hukum.

Teknik Pengumpulan Data dilakukan dengan cara peneletian kepustakaan (library research), yaitu penelitian yang dilakukan dengan cara meneliti bahan pustaka atau bahan yang disebut dengan data sekunder.

Bahan Hukum yang telah dikumpulkan kemudian dianalisis dengan menggunakan analisis kualitatif deskriptif, yaitu analisis dengan cara menggambarkan dan mengkaji bahan hukum kepustakaan dalam bentuk pernyataan atau katakata dengan teliti dan sistematis.

\section{HASIL PENELITIAN DAN PEMBAHASAN}

\section{Pengaturan kedudukan Akta Fidusia dan peran Notaris dalam pembuatan Akta Fidusia}

Menurut G.H.S. Lumban Tobing, wewenang utama notaris yaitu untuk membuat akta otentik. Otentisitas dari akta notaris bersumber dari Pasal 1 Peraturan Jabatan Notaris dimana notaris dijadikan sebagai "pejabat umum", sehingga akta yang dibuat oleh notaris karena kedudukannya tersebut memperoleh sifat sebagai akta otentik. ${ }^{4}$

Kewenangan notaris ini meliputi 4 hal, yaitu:

1) Sepanjang yang menyangkut akta yang dibuatnya itu.

2) Sepanjang mengenai orang -orang, untuk kepentingan siapa akta itu dibuat.

3) Sepanjang mengenai tempat, dimana akta itu dibuat.

4) Sepanjang mengenai waktu pembuatan akta itu.

Ruang lingkup pertanggung jawaban notaris meliputi kebenaran materiil atas akta yang dibuatnya. Nico membedakannya menjadi empat poin yakni : ${ }^{5}$

1) Secara perdata terhadap kebenaran materiil terhadapakta yang dibuatnya;

2) Secara pidana terhadap kebenaran materiil dalam aktayang dibuatnya;

3) Berdasarkan Peraturan Jabatan Notaris terhadap kebenaran materiil dalamakta yang dibuatnya;

4 G.H.S. Lumban Tobing, Peraturan Jabatan Notaris, Jakarta: Erlangga, 2012, Cetakan ke 4, hlm.48

${ }^{5}$ Nico, Tanggungjawab Notaris Selaku Pejabat Umum, Yogyakarta: Center for Documentation and Studies of Business Law, 2003, hlm. 21.
4) Dalam menjalankan tugas jabatannya berdasarkankode etik Notaris.

Kewenangan Notaris tersebut dalam Pasal 15 dari ayat (1) sampai dengan ayat (3) UUJN, dibagi menjadi :

1) Kewenangan Umum Notaris. Pasal 15 ayat (1) UUJN menegaskan bahwa salah satu kewenangan Notaris yaitu membuat akta secara umum dengan batasan sepanjang :

a. Tidak dikecualikan kepada pejabat lain yang telah ditetapkan oleh undang-undang.

b. Akta yang harus dibuat adalah akta otentik mengenai semua perbuatan, perjanjian dan ketetapan yang diharuskan oleh aturan hukum untuk dibuat atau dikehendaki oleh yang bersangkutan.

c. Kepentingan subjek hukumnya yaitu harus jelas untuk kepentingan siapa suatu akta itu dibuat.

d. Akta otentik yang merupakan wewenang Notaris dan juga menjadi wewenang pejabat atau instansi lain, yaitu:

1) Akta pengakuan anak di luar kawin (Pasal $281 \mathrm{BW}$ ),

2) Akta berita acara tentang kelalaian pejabat penyimpan hipotik (Pasal 1227 BW),

3) Akta berita acara tentang penawaran pembayaran tunai dan konsinyasi (Pasal 1405,1406 BW),

4) Akta protes wesel dan cek (Pasal 143 dan 218 WvK),

5) Surat kuasa membebankan Hak Tanggungan (Pasal 15 ayat [1] UU No.4 Tahun 1996),

Berdasarkan wewenang yang ada pada Notaris sebagaimana tersebut dalam Pasal 15 UUJN dan kekuatan pembuktian dari akta Notaris, maka ada 2 hal yang dapat kita pahami, yaitu: Notaris dalam tugas jabatannya memformulasikan keinginan/tindakan para pihak ke dalam akta otentik, dengan memperhatikan aturan hukum yang berlaku; Akta Notaris sebagai akta otentik mempunyai kekuatan pembuktian yang sempurna, sehingga tidak perlu dibuktikan atau ditambah dengan alat bukti yang lainnya.

2) Kewenangan Khusus Notaris.

Pasal 15 ayat (2) UUJN, yang mengatur mengenai kewenangan khusus Notaris untuk melakukan tindakan hukum tertentu, seperti:

a. Mengesahkan tanda tangan dan menetapkan kepastian tanggal surat di bawah tangan dengan mendaftarkannya di dalam suatu buku khusus;

b. Membukukan surat-surat di bawah tangan 
dengan mendaftarkannya dalam suatu buku khusus;

c. Membuat salinan (copy) asli dari surat-surat di bawah tangan berupa salinan yang memuat uraian sebagaimana ditulis dan digambarkan dalam surat yang bersangkutan;

d. Melakukan pengesahan kecocokan antara fotokopi dengan surat aslinya;

e. Memberikan penyuluhan hukum sehubungan dengan pembuatan akta;

f. Membuat akta yang berkaitan dengan pertanahan, atau

g. Membuat akta risalah lelang.

Pasal 15 ayat (2) huruf j UUJN memberikan kewenangan kepada notaris untuk membuat akta di bidang pertanahan, yaitu : Notaris telah mengambil alih semua wewenang PPAT menjadi wewenang Notaris atau telah menambah wewenang notaris; Bidang pertanahan juga ikut menjadi wewenang notaris.

3) Kewenangan Notaris yang akan ditentukan kemudian.

Dalam Pasal 15 ayat (3) UUJN, dengan kewenangan yang akan ditentukan kemudian adalah wewenang yang berdasarkan aturan hukum lain yang akan datang kemudian (ius constituendum). Batasan mengenai apa yang dimaksud dengan peraturan perundangundangan ini dapat dilihat dalam Pasal 1 angka 2 Undang-Undang No. 5 Tahun 1986 tentang Peradilan Tata Usaha Negara.

Undang-undang Nomor 2 Tahun 2014 Tentang Jabatan Notaris Pasal 15 ayat (1) "Notaris berwenang membuat Akta otentik mengenai semua perbuatan, perjanjian, dan penetapan yang diharuskan oleh peraturan perundang-undangan dan/atau yang dikehendaki oleh yang berkepentingan untuk dinyatakan dalam Akta Otentik, menjamin kepastian tanggal pembuatan Akta, menyimpan Akta, memberikan grosse, salinan dan kutipan Akta, semuanya itu sepanjang pembuatan Akta itu tidak juga ditugaskan atau dikecualikan kepada pejabat lain atau orang lain.

Jaminan Fidusia bersifat accessoir, tercantum dalam Pasal 4 Undang-Undang Nomor 42 Tahun 1999 Tentang Jaminan Fidusia, yaitu "Jaminan Fidusia merupakan perjanjian ikutan dari suatu perjanjian pokok bukan kewajiban bagi para pihak untuk memenuhi suatu prestasi".

\section{Keabsahan Seorang Notaris Membuat Akta Fidusia diluar Wilayah Jabatannya}

Keabsahan suatu perjanjian yang diatur dalam Pasal 1320 KUHPerdata menyebutkan bahwa syarat sah obyektif yang harus dipenuhi ialah sebab yang halal dan suatu hal tertentu. Notaris sebagai satusatunya pejabat publik yang diberikan kewenangan untuk membuat Akta Jaminan Fidusia dan memiliki tanggungjawab yang sangat penting terhadap keabsahan akta fidusia yang telah dibuatnya.

Menurut Pasal 1868 KUHPerdata, yang dimaksud dengan akta autentik adalah suatu akta yang dibuat dalam bentuk yang ditentukan oleh undang-undang atau dihadapan pejabat umum yang berwenang untuk itu di tempat akta itu dibuat apabila telah memenuhi unsur-unsur sebagai berikut, yaitu: 1) Dibuat dalam bentuk yang ditentukan oleh undang-undang; 2) Dibuat oleh atau di hadapan pejabat umum yang berwenang untuk maksud pembuatan akta tersebut; 3) Dibuat di wilayah notaris berwenang.

Pasal 1868 KUHPerdata menyatakan "Akta yang dibuat oleh atau dihadapan" menunjukkan adanya 2 (dua) golongan bentuk Akta Notaris yaitu':

1) Dibuat oleh (door) Notaris atau yang dinamakan Akta relaas atau Akta Pejabat (ambtelijke akten),

2) Dibuat dihadapan (ten overstaan) Notaris atau yang dinamakan Akta partij (partij-akten) atau disebut juga Akta para pihak. Akta partij atau akta pihak (partij akten).

Akta yang dibuat dihadapan atau oleh Notaris bentuknya sudah ditentukan dalam Pasal 38 UUJN. Adapun unsur-unsurnya meliputi sebagai berikut : Awal ( permulaan/kepala) akta; Komparisi; Premise (recitals) akta; Isi/badan akta; Akhir/ penutup akta Setiap penghadap yang membuat akta dihadapan notaris harus tercantum dalam komparisi akta.

Menurut UUJN yakni Pasal 15 Ayat (1), kewenangan Notaris adalah membuat akta dengan batasan : 1) Tidak dikecualikan pada pejabat lain yang ditetapkan oleh Undang-undang; 2) Menyangkut akta yang harus dibuat atau berwenang membuat akta otentik mengenai semua perbuatan, perjanjian, dan ketetapan yang diharuskan oleh aturan hukum atau dikehendaki oleh yang bersangkutan; 3) Mengenai subjek hukum untuk kepentingan siapa akta itu dibuat.

Notaris berwenang pula membuat akta In Originali (meski dalam UUJN dimasukkan dalam ketentuan Pasal 16 Ayat (2) dan (3), namun jika melihat substansinya maka hal tersebut merupakan kewenangan Notaris) yakni: Pembayaran uang sewa, bunga, dan pensiun;Penawaran pembayaran tunai; Protes terhadap tidak dibayarnya atau tidak diterimanya surat berharga;Akta kuasa;Keterangan

6 Herlien Budiono, Kumpulan Tulisan Hukum Perdata di Bidang Kenotariatan, Citra Aditya Bakti, Bandung, 2007, hlm 51-52. 
kepemilikan; atau Akta lainnya berdasarkan peraturan perundang-undangan.

\section{Kedudukan Akta Fidusia yang dibuat Notaris diluar wilayah jabatannya}

Dalam pembuatan akta autentik hal yang perlu diperhatikan adalah walaupun semua syarat dan unsur-unsur akta autentik telah terpenuhi, suatu akta autentik dapat dikatakan autentik jika akta tersebut sepanjang tidak ada orang atau pihak yang mempermasalahkan dan membuktikan keautentikan akta tersebut, maka Akta itu tetap dianggap sah demi hukum.

Mengenai tanggung jawab notaris selaku pejabat umum berhubungan dengan kebenaran materil dibedakan empat poin yaitu: ${ }^{7}$

1) Tanggung jawab notaris secara perdata terhadap kebenaran materil terhadap akta yang dibuatnya.

2) Tanggung jawab notaris secara pidana terhadap kebenaran materil dalam kata yang dibuatnya.

3) Tanggung jawab motaris berdasarkan peraturan jabatan notaris terhadap kebenaran materil dalam akta yang dibuatnya.

4) Tanggung jawab notaris dalam menjalankan tugas dan jabatanya berdasarkan kode etik notaris.

Abdul Kadir Muhammad, notaris dalam menjalankan tugas dan jabatanya harus bertanggung jawab, artinya : ${ }^{8}$

1) Notaris dituntut melakukan pembuatan akta dengan baik dan benar

2) Notaris dituntut menghasilkan akta yang bermutu

3) Berdampak positif

Ruang lingkup pertanggung jawaban notaris meliputi kebenaran materiil, dapat dibagi menjadi empat poin : 1) Tanggung jawab notaris secara perdata terhadap kebenaran materil terhadap akta yang dibuatnya; 2) Tanggung jawab notaris secara pidana terhadap kebenaran materil dalam kata yang dibuatnya; 3) Tanggung jawab motaris berdasarkan peraturan jabatan notaris terhadap kebenaran materil dalam akta yang dibuatnya; 4) Tanggung jawab notaris dalam menjalankan tugas dan jabatanya berdasarkan kode etik notaris.

Adapun faktor-faktor yang dapat menyebabkan suatu akta dapat dibatalkan adalah: Adanya kesalahan dalam proses pembuatan akta yang tidak sesuai dengan Undang-undang; Adanya kesalahan ketikan pada salinan akta notaris; Adanya kesalahan bentuk akta notaris; Adanya kesalahan atas isi akta

\footnotetext{
${ }^{7}$ Abdul Ghofur Anshori, Filsafat Hukum, Gadjah Mada University Press, Yogyakarta, 2009, hlm 34-36

${ }^{8}$ Abdul Kadir Muhammad, Hukum Perdata Indonesia, Citra Aditya Bakti, Bandung, 1993, hlm 49
}

notaris; Adanya perbuatan melawan hukum yang dilakukan notaris dalam pembuatan akta.

Pasal 17 Undang-Undang Nomor 30 Tahun 2004 tentang Jabatan Notaris, akan tetapi adanya Undang-Undang Nomor 2 Tahun 2014 tentang perubahan atas Undang-Undang Nomor 30 Tahun 2004 tentang Jabatan Notaris, ketentuan Pasal 17 diubah sehingga berbunyi sebagai berikut:

1) Notaris dilarang: Menjalankan jabatan diluar wilayah jabatanya; Meninggalkan wilayah jabatanya lebih dari 7 (tujuh) hari kerja berturutturut tanpa alasan yang sah; Merangkap jabatan sebagai pegawai negeri; Merangkap jabatan sebagai pejabat negara; Merangkap jabatan sebagai advokat; Merangkap jabatan sebagai pemimpin atau pegawai badan usaha milik negara, badan usaha milik daerah atau badan usaha swasta; Merangkap jabatan sebagai pejabat pembuat Akta Tanah dan/ atau Pejabat lelang Kelas II di luar tempat kedudukan notaris; Menjadi notaris pengganti; atau Melakukan pekerjaan lain bertentangan dengan norma agama, kesusilaan, atau kepatutan yang dapat memperngaruhi kehormatan dan martabat jabatan notaris.

2) Notaris yang melanggar ketentuan sebagaimana dimaksud pada ayat (1) dapat dikenai sanksi berupa: a. Peringatan tertulis; b. Pemberhentian sementara; c. Pemberhentian dengan hormat; atau d. Pemberhentian dengan tidak hormat.

Larangan-larangan Notaris telah diatur sedemikian rupa dalam kode Etik Notaris yang tercantum dalam Pasal $4 \mathrm{sbb}$ :

1) Mempunyai lebih dari 1 (satu) kantor, baik kantor cabang ataupun kantor perwakilan.

2) Memasang papan nama dan/ atau tulisan yang berbunyi "Notaris/Kantor Notaris" di luar lingkungan kantor.

3) Melakukan publikasi atau promosi diri, baik sendiri maupun secara bersama-sama dalam bentuk: a. Iklan; b. Ucapan selamat; c. Ucapan terima kasih; d. Kegiatan pemasaran; e. Kegiatan sponsor, baik dalam bidang sosial, keagamaan, maupun olahraga.

4) Bekerja sama dengan biro jasa/badan hukum sebagai perantara mendapatkan klien.

5) Menandatangani akta yang proses pembuatan minutanya telah dipersiapkan oleh pihak lain.

6) Mengirimkan minuta kepada klien untuk ditandantangani.

7) Berusaha atau berupaya dengan jalan apapun, agar seseorang berpindah dari Notaris lain kepadanya.

8) Melakukan pemaksaan kepada klien dengan cara menahan dokumen-dokumen dan/atau 
melakukan tekanan psikologis agar klien membuat akta kepadanya.

9) Melakukan usaha-usaha, yang menjurus kearah timbulnya persaingan yang tidak sehat dengan sesama rekan notaris.

10) Menetapkan honorarium yang harus dibayar oleh klien dalam jumlah yang lebih rendah dari honorarium yang ditetapkan perkumpulan.

11) Memperkerjakan dengan sengaja orang masih berstatus karyawan kantor notaris lain tanpa persetujuan dari notaris yang bersangkutan;

12) Menjelaskan dan/atau mempersalahkan rekan notaris atau akta yang dibuat olehnya.

13) Tidak melakukan kewajiban dan melakukan pelanggaran sebagaimana dimaksud dalam kode Etik dengan menggunakan media elektronik;

14) Membentuk kelompok sesama rekan sejawat dengan tujuan melayani kepentingan suatu instansi atau lembaga;

15) Menggunakan/mencantumkan gelar yang tidak sesuai peraturan perundang-undangan;

16) Membuat akta melebihi batas kewajaran yang batas jumlahnya di tentukan oleh Dewan Kehormatan;

17) Mengikuti pelelangan untuk mendapatkan pekerjaan/pembuatan akta.

\section{PENUTUP}

\section{Kesimpulan}

1) Pengaturan Kedudukan Akta Fidusia dan Peran Notaris dalam Pembuatan Akta Fidusia. Pasal 5 Ayat (1) Undang- Undang Nomor 42 tahun 1999 tentang Jaminan Fidusia menyebutkan bahwa yang berwenang membuat Akta Fidusia adalah seorang notaris, sedangkan Pasal 17 UndangUndang Nomor 2 Tahun 2014 perubahan atas Undang-Undang Nomor 30 Tahun 2004 Tentang Jabatan Notaris yang mengatur bahwa Notaris hanya berwenang untuk membuat akta otentik diwilayah hukum atau wilayah jabatannya.

2) Akibat Seorang Notaris membuat Akta Fidusia diluar wilayah Jabatannya yaitu Mendapatkan sanksi berupa teguran lisan dan teguran tulis yang selanjutnya akan dijatuhi sanksi administratif, sanksi bisa berupa pemberhentian sementara, pemberhentian dengan hormat jika kesalahan fatal diberikan sanksi pemberhentian secara tidak hormat.

3) Kedudukan Akta Fidusia yang dibuat Notaris diluar wilayah Jabatannya akta notaris tersebut tidak otentik dan akta tersebut tidak memiliki kekuatan seperti akta dibawah tangan apabila ditanda tangani oleh para pihak yang bersangkutan. Kebatalan akta notaris meliputi; dapat dibatalkan, batal demi hukum, mempunyai kekuatan pembuktian sebagai akta dibawah tangan.

\section{Saran}

1) Seorang notaris dilarang melaksanakan pembuatan akta notaris jabatan diluar wilayah jabatanya dapat melaksanakan tugas jabatan tersebut di luar tempat kedudukanya akan tetapi dengan syarat masih berada dalam wilayah jabatanya.

2) Notaris yang mempunyai domisili dan berada diluar wilayah jabatannya, sebaiknya secara bertahap berusaha untuk berpindah tempat tinggal atau tidak mengambil kewenangan, tugas serta kewajiban yang memang diluar wilayah jabatanya.

\section{DAFTAR PUSTAKA}

Abdul Ghofur Anshori, 2009, Filsafat Hukum, Gadjah Mada University Press, Yogyakarta

Abdul Kadir Muhammad,1993, Hukum Perdata Indonesia, Citra Aditya Bakti, Bandung

G.H.S. Lumban Tobing, 2012, Peraturan Jabatan Notaris, Jakarta: Erlangga, Cetakan ke 4

Herlien Budiono, 2007, Kumpulan Tulisan Hukum Perdata di Bidang Kenotariatan, Citra Aditya Bakti, Bandung

Ignatius Ridwan Widyadarma, 1996, Undang-Undang Hak Tanggungan atas Tanah beserta BendaBenda yang Berkaitan dengan Tanah,Badan Penerbit Universitas Diponegoro, Semarang

Mariam D. Badrulzaman, 1978, Bab - Bab Tentang Credietverband, Gadai dan Fidusia, Alumni, Bandung

Nico, Tanggungjawab Notaris Selaku Pejabat Umum, 2003, Yogyakarta: Center for Documentation and Studies of Business Law

Purwahid Patrik, Kashadi, 2009, Hukum Jaminan, Badan Penerbit Universitas Diponegoro, Semarang

Tan Thong Kie, Buku I Studi dan Serba Serbi Praktek Notariat, 2000 , Ichtiar Baru Van Hoeve, Jakarta. 